\title{
Evaluation of Effect of Silage Prepared from Parthenium hysterophorous (Congress Grass) and Cannabis sps. (Hemp) with Maize on the Performance of Goats
}

\author{
Mohd Iqbal, R.K. Sharma, Ankur Rastogi, Shamim Ali* and Danish Bhutyal \\ Division of Animal Nutrition, SKUAST Jammu, India
}

*Corresponding author

\section{A B S T R A C T}

\section{Keywords \\ Cannabis, Hemp, Parthenium hysterophorus, Goats, Silage}

\section{Article Info}

Accepted:

24 October 2018

Available Online:

10 December 2018
The present study evaluated the silage prepared from Parthenium- Cannabis-Maize mix $(30: 8: 60+2$ molasses) (PCM) and its utilization by goats. Twelve non-descript local adults male goats was randomly divided into two equal groups as per randomized block design and were fed either maize silage or PCM silage ad libitum supplemented with concentrate mixture @ $20 \mathrm{~g} / \mathrm{KgW}^{0.75}$. The feeding trial was of 30 days duration along with a digestion-cum-metabolism trial during last week of the feeding trial. Final $\mathrm{pH}$ of the MS and PCM silage was 5.72 and 5.60, respectively. Mean concentration of $\mathrm{NH}_{3}-\mathrm{N}$ (as percentage of total $\mathrm{N}$ ) was significantly higher in MS silage. Body weight of the animals was maintained throughout the trial in both groups. Silage intake was significantly higher in MS group. Digestibility (\%) of CF and NDF was significantly higher in MS fed goats, however, DM, OM, CP, EE, NFE and ADF digestibility was comparable between groups. Daily intake of nitrogen was significantly higher in MS group, leading to lower net balance in PCM fed animals.

\section{Introduction}

Parthenium hysterophorous (Congress grass) is an obnoxious weed (Khaket et al., 2015), that has spread rapidly and extensively throughout the world since the 1970s (Evans, 1997) and is considered as one of the World's seven most damaging weeds (Ghosh et al., 2012 and Kushwaha and Maurya, 2012). It was accidentally introduced into India as a contaminant in PL 480 wheat imported from United States of America in 1950s (Singh et al., 2008) and is now estimated to occupy more than 5 million hectares of land in the
India (Kumar and Kumar, 2010). It is a cause of concern for agriculturists, livestock farmers, town planners etc. The toxic effects of parthenium are exerted as contact dermatitis and air borne dermatitis, fever and asthma The primary active ingredient responsible for toxic effects is a sesquiterpene lactone-parthenin.It was shown to be responsible for chronic as well as acute toxicity in livestock.As a weed, parthenium is nutrient aggregator and is therefore rich in nutrients (Bhoyar et al., 2014) which indicate that parthenium herbage in its unprocessed fresh form can be extremely toxic to livestock. 
However Hemp (Cannabis sps.) is another infamous plant that has invaded vast land area in India including Jammu. It is one of the oldest and fastest growing plants known to man (Nelson, 2000). Despite its many uses (fibre, oil, medicine, food), its cultivation is restricted. Its growth in public places and wasteland leads to its undesirable use as a hallucinogen due to the presence of tetrahydrocannabinol (THC), a psychotropic chemical (Febles, 2018).The cultivation of Cannabis sps. is highly regulated by the government through law (Butsic and Brenner, 2016).Wasteland invasion by this plant makes such regulatory provisions ineffective and therefore its containment as a weed is desirable. Their management is a difficult task due to high proliferation rate and ecological adaptability (Saini et al., 2014). Large scale utilization of weeds can be an attractive alternative to economically signify as well as manage hazardous weeds (APFISN, 2007; Javaid and Shahfique, 2010). Capability of weed to function as a source of feed additive, and animal feed after ensilage opens more directions for utilization of these weed (Saini et al., 2014).

\section{Materials and Methods}

The study was conducted during the months of September-January at R S Pura, Jammu. Maize fodder was procured from a farmer's field near Domana, Jammu. The harvesting was done near milk stage. Concurrently, whole plants of parthenium (Parthenium hysterophorus) and hemp (Cannabis sp.) were collected from the premises of SKUAST-J, RS Pura, Jammu.The samples of all three plants were analyzed for chemical composition (proximate analysis, fiber fractionation, calcium and phosphorus content).All the collected plants were chopped separately into 2-3 cms long pieces using a electric motor driven chaff cutter. Ensiling was done in multiple large polythene bags of approximately $50 \mathrm{~kg}$ capacity each. Silage was prepared from the Maize fodder which serves as a control silage (MS). Based on the chemical coposition of the plant samples (Table 1), a combination of Parthenium (30\%), Cannabis (8\%) and Maize (60\%) alongwith $2 \%$ molasses (all fresh weight basis) were mixed together and ensiled to serve as Treatment silage (PCM). The polythene bags were filled with respective material to be ensiled, hand pressed and closed tightly using a string. Further, the string tied bags were also sealed Mud pack. The sealed bags were stored in godown in shade on a raised platform in shade. Silo bags were allowed 90 days incubation period. Bags were opened one at a time after incubation period for the purpose of feeding trial. Along with ensiling for feeding trial in silo bags, a laboratory level ensiling of MS and PCM were also done in multiple replicates from same lot of chopped plant material. This ensiling was done in 500 gms capacity zip lock polythene bags. The $\mathrm{pH}$ content of ensiled material was estimated at the start of incubation period and then at fortnightly intervals. The $\mathrm{pH}$ was measured in triplicates by randomly selecting three zip lock bags of each type of silage and taking representative sample of silage (about $10 \mathrm{gms})$ from each bag in a glass beaker (100 $\mathrm{ml}$. capacity) along with $20 \mathrm{ml}$. of distilled water at room temperature. Twelve local, nondescript, adult male goats (10-14 months age; $28.90 \pm 1.64 \mathrm{~kg}$ live weight) were randomly allotted to two equal groups ( $n=6$ per group) namely, MS and PCM as per randomized block design.All the experimental goats were kept under uniform management conditions with the provision of individually feeding in well ventilated cement floored sheds. The goats were treated for ecto- and endo-parasites with Butox ${ }^{(\mathrm{R})}$ spray and Panacur $^{(\mathrm{R})}$ bolus, respectively before the start of study. Clean, wholesome drinking water was provided twice daily on ad libitum basis. All the experimental goats were managed on ad libitum silage 
supplemented with concentrate mixture@ $20 \mathrm{~g} / \mathrm{KgW}^{0.75}$ feeding regimen. The MS group was offered maize silage and PCM group was kept on Parthenium-Cannabis-Maize silage prepared as per sub-section 3.3. Both the groups were supplemented with concentrate mixture of similar composition (Maize-25\%, Mustard oil cake-37\%, Wheat bran-35\%, Mineral ixture-2\% and common salt-1\%). The concentrate mixture was formulated to satisfy the nutrient requirements of goats as per ICAR (2013). Weighed quantities of respective concentrate mixtures were offered to goats at $0900 \mathrm{hr}$ in the morning and $1700 \mathrm{hr}$ in the evening (total allowance as per $20 \mathrm{~g} / \mathrm{kgW}^{0.75}$ divided in two equal parts). Ad libitum silage was offered after the consumption of complete concentrate mixtures both in morning and evening hrs. Concentrate and silage offered and residue left from each goat were sampled weekly for subsequent analysis of DM to assess average DM consumption during the experimental period.

Body weight of each goat before feeding and watering was recorded at the start of experiment and then at weekly intervals to observe live weight changes. To assess the nutrient intake and digestibility, plane of nutrition and balance of nitrogen, calcium and phosphorus, a digestion-cum-metabolism trial of one week duration was conducted in the last week of experimental feeding. Trial was conducted by housing all the animals individually with arrangements for quantitative collection of faeces and urine separately. The data obtained from chemical analysis of feedstuffs and metabolism trial was subjected to one- way ANOVA, whereas observations of daily dry matter intake, body weight and blood parameters was subjected to multivariate analysis (Snedecor and Cochran, 1994). The means bearing significant difference were ranked by Duncan's multiple range test as per Duncan (1955).

\section{Results and Discussion}

The chemical composition details of the analysed feedstuffs are presented in table 1. The $P$. hysterophorous whole plant was found to contain $87.14 \% \mathrm{OM}, 37.68 \% \mathrm{CP}, 34.11 \%$ NDF, $26.14 \%$ ADF, $0.54 \%$ calcium and $0.46 \%$ phosphorus, whereas Cannabis sps. contained $82.45 \% \mathrm{OM}, 28.13 \% \mathrm{CP}, 44.12 \%$ NDF, $19.00 \%$ ADF, $0.46 \%$ calcium and $0.48 \%$ phosphorus. The proximate composition and fiber fractions of parthenium and Cannabis sps., Maize silage (MS) and Parthenium-Cannabis-Maize (PCM) silage, and concentrate mixture used in the study are presented in Table 1. The DM, CP and CF contents of MS are 38.67, 13.22, and 43.19 per cent, respectively, while, that of PCM silage are 24.63, 17.49 and 47.14 per cent, respectively.The NDF and ADF content of the silages was 37.14 and 35.17 per cent, respectively for MS, while that of PCM silage was 21.07 and 40.09, respectively. The MS and PCM silages differed significantly $(\mathrm{P}<0.01)$ for all analysed parameters, except per cent $\mathrm{OM}$ and calcium and phosphorus content $(\mathrm{P}>0.05)$. The concentrate mixture fed to experimental goats in feeding trial contained $92.39 \pm 0.98 \% \quad \mathrm{OM}, \quad 23.37 \pm 0.24 \%$ $\mathrm{CP}, \quad 44.35 \pm 0.14 \% \mathrm{NDF}$ and $12.40 \pm 0.14 \%$ ADF. The calcium and phosphorus content of the concentrate mixture was $0.94 \pm 0.01$ and $0.52 \pm 0.01$ per cent, respectively. Fortnightly state of fermentation evaluated as $\mathrm{pH}$ and $\mathrm{NH}_{3}-\mathrm{N}$ (ammonia nitrogen) concentration for MS and PCM silages used in feeding trial is presented in table 2 and figure 1 . The final $\mathrm{pH}$ of the MS and PCM silage was 5.72 and 5.60, respectively. There was significant difference $(\mathrm{P}<0.01)$ between treatments and between periods. The mean $\mathrm{pH}$ decreased from $7.04 \pm 0.02$ at the start of ensiling to significantly lower $(\mathrm{P}<0.01) \mathrm{pH}$ with each fortnight. Further, there was significant treatment and period interaction $(\mathrm{P}<0.01)$. $\mathrm{NH}_{3}-\mathrm{N}$ concentration was expressed as 
percentage of total $\mathrm{N}$ concentration in the silage. The mean concentration of $\mathrm{NH}_{3}-\mathrm{N}$ in PCM silage (8.49 \pm 0.78$)$ was significantly higher than that in MS silage $(5.13 \pm 0.44)$. There was significant increase $(\mathrm{P}<0.01)$ in $\mathrm{NH}_{3}-\mathrm{N}$ concentration after a month of ensiling (between $30^{\text {th }}$ and $45^{\text {th }}$ day observation) followed by steady increase till the end of incubation period $\left(90^{\text {th }}\right.$ day). Significant $(\mathrm{P}<0.01)$ treatment and period interaction was also observed.

The periodic body weight of experimental goats is presented in Table 3. Overall mean body weight of the experimental animals was $27.10 \pm 0.80 \mathrm{~kg}$ with that of MS group as $26.8 \pm 1.18 \mathrm{~kg}$ and that of PCM group as $27.4 \pm 1.09$. Body weight of the animals did not vary significantly between periods $(\mathrm{P}>0.05)$ and between groups $(\mathrm{P}>0.05)$.

The feed intake of experimental goats in terms of concentrate mixture, silages and total intake were recorded daily and is presented week wise as mean daily intake in table 4 and is depicted in figure 2 . The concentrate intake (dry matter basis; DMB) was similar $(\mathrm{P}>0.05)$ across the treatment groups and periods, without any significant $(\mathrm{P}>0.05)$ interaction between both. The mean concentrate intake for experimental goats was $220 \pm 1.96 \mathrm{~g} / \mathrm{d}$. Mean Silage intake (DMB) and total feed intake (DMB) of experimental animals was $516 \pm 9.55 \mathrm{~g} / \mathrm{d}$ and $736 \pm 9.65 \mathrm{~g} / \mathrm{d}$, respectively. Silage intake and total feed intake was significantly higher $(\mathrm{P}<0.01)$ in MS group $(672 \pm 7.39 \mathrm{~g} / \mathrm{d} ; 891 \pm 8.02 \mathrm{~g} / \mathrm{d})$ as compared to that of PCM group $(359 \pm 6.15 \mathrm{~g} / \mathrm{d} ; 581 \pm 6.46$ $\mathrm{g} / \mathrm{d})$ and it also increased significantly $(\mathrm{P}<0.01)$ with each passing week of the feeding trial with lowest intake in week I and highest intake in week IV. Significant interaction $(\mathrm{P}>0.05)$ was observed between treatment groups and period of observation with respect to silage and total feed intake. Effect of feeding MS and PCM silage on nutrient intake viz. dry matter intake (DMI), organic matter intake (OMI) and crude protein intake (CPI) expressed as $\mathrm{g} / \mathrm{d}$, percentage of live weight and $\mathrm{g} / \mathrm{kg} \mathrm{W}^{0.75}$ during feeding trial in goats is presented in table 5 .

Fig.1 Periodic rate of fermentation assay for silages

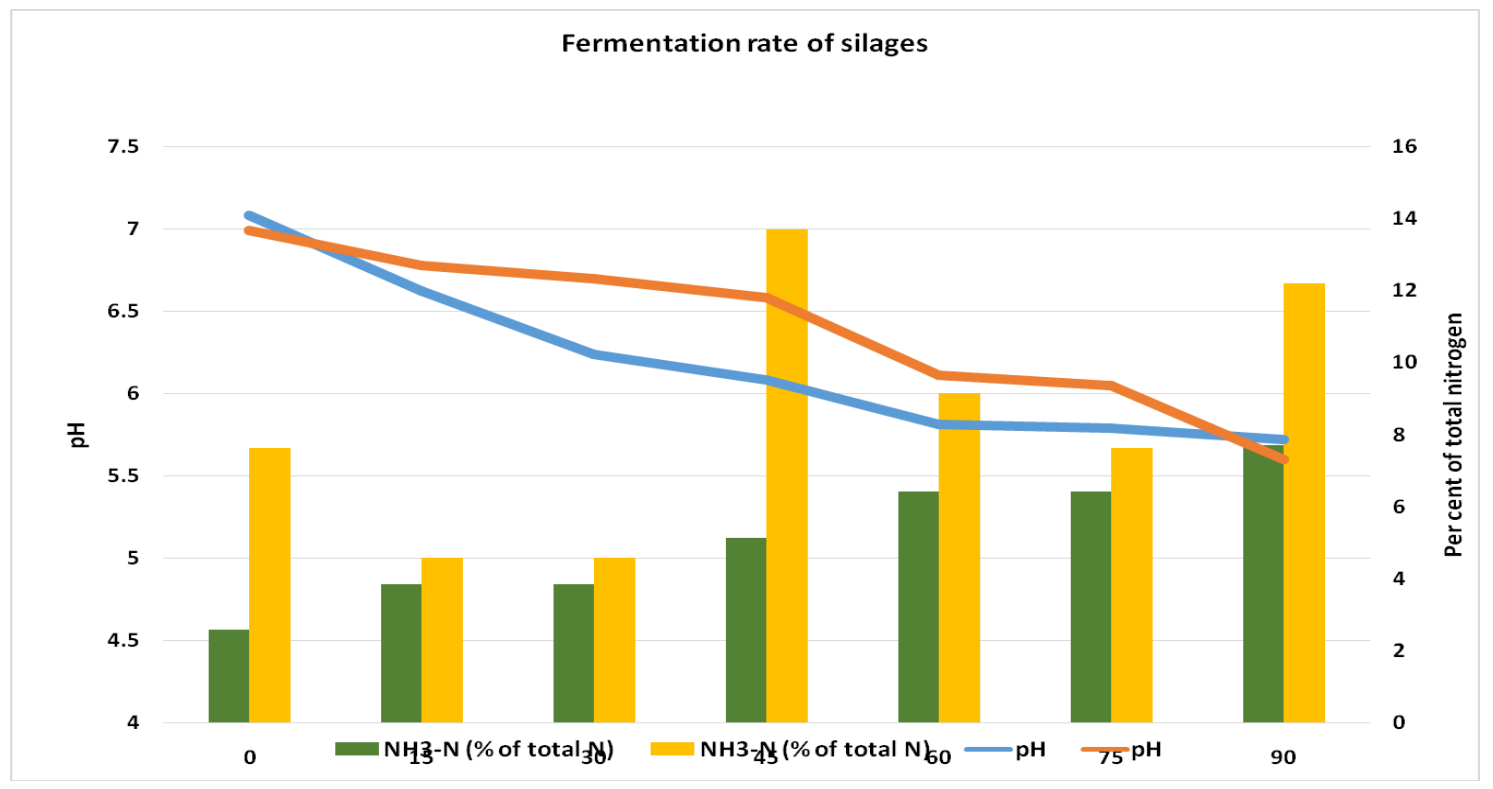


Table.1 Chemical composition $(\%)^{\#}$ of the weed samples, silages and concentrate mixture used in feeding-cum-metabolism trial

\begin{tabular}{|c|c|c|c|c|c|c|c|}
\hline \multirow[t]{2}{*}{ Attributes $^{\wedge}$} & \multicolumn{2}{|c|}{ Weed samples } & \multicolumn{4}{|c|}{ Silage as per Treatments* } & \multirow{2}{*}{$\begin{array}{l}\text { Concentrate } \\
\text { mixture }\end{array}$} \\
\hline & $\begin{array}{c}\text { Parthenium } \\
\text { hysterophorous }\end{array}$ & $\begin{array}{c}\text { Cannabis } \\
\text { sps. }\end{array}$ & MS & PCM & SEM & $\begin{array}{c}\mathbf{P} \\
\text { value }\end{array}$ & \\
\hline Dry Matter & 24.38 & 40.94 & 38.67 & 24.63 & 3.15 & 0.000 & $92.24 \pm 1.02$ \\
\hline $\begin{array}{c}\text { Organic } \\
\text { matter }\end{array}$ & 87.14 & 82.45 & 86.09 & 86.24 & 0.04 & 0.062 & $92.39 \pm 0.98$ \\
\hline $\begin{array}{l}\text { Crude } \\
\text { Protein }\end{array}$ & 37.68 & 28.13 & 13.22 & 17.49 & 0.96 & 0.000 & $23.37 \pm 0.24$ \\
\hline Ether extract & 6.52 & 7.51 & 6.03 & 7.51 & 0.34 & 0.000 & $7.50 \pm 0.07$ \\
\hline Crude fibre & 41.42 & 44.29 & 43.19 & 47.14 & 0.91 & 0.001 & $4.54 \pm 0.15$ \\
\hline $\begin{array}{c}\text { Nitrogen } \\
\text { free extract }\end{array}$ & 1.52 & 2.51 & 23.64 & 14.1 & 2.16 & 0.000 & $57.21 \pm 1.09$ \\
\hline $\begin{array}{c}\text { Neutral } \\
\text { detergent } \\
\text { fibre }\end{array}$ & 34.11 & 44.12 & 37.14 & 21.07 & 3.59 & 0.000 & $44.35 \pm 0.14$ \\
\hline $\begin{array}{c}\text { Acid } \\
\text { detergent } \\
\text { fibre }\end{array}$ & 26.14 & 19.00 & 35.17 & 40.09 & 1.11 & 0.000 & $12.40 \pm 0.14$ \\
\hline Calcium & 0.54 & 0.46 & 0.26 & 0.25 & 0.001 & 0.453 & $0.94 \pm 0.01$ \\
\hline Phosphorous & 0.46 & 0.48 & 0.48 & 0.47 & 0.001 & 0.169 & $0.52 \pm 0.01$ \\
\hline
\end{tabular}

${ }^{\#}$ Each value is a mean of 3 observations

*MS: Maize silage; PCM: Parthenium-Cannabis-Maize silage (30:8:60+ 2 Molasses)

${ }^{\wedge}$ All values are on dry matter basis except dry matter 
Int.J.Curr.Microbiol.App.Sci (2018) 7(12): $3245-3255$

Table.2 Periodic rate of fermentation assay for silages used in feeding trial

\begin{tabular}{|c|c|c|c|c|c|c|c|c|c|c|c|}
\hline \multirow{2}{*}{$\begin{array}{l}\text { Attribute/ } \\
\text { Treatments } \\
*\end{array}$} & \multicolumn{7}{|c|}{ Days since filling of silo bags } & \multirow{2}{*}{$\begin{array}{c}\text { Treatmen } \\
\text { t Mean } \pm \\
\text { SEM }\end{array}$} & \multicolumn{3}{|c|}{ P value ${ }^{\#}$} \\
\hline & $\mathbf{0}$ & 15 & 30 & 45 & 60 & 75 & 90 & & $\mathbf{T}$ & $\mathbf{P}$ & $\mathbf{T} \times \mathbf{P}$ \\
\hline \multicolumn{12}{|l|}{ pH } \\
\hline MS & 7.08 & 6.62 & 6.24 & 6.08 & 5.81 & 5.79 & 5.72 & $6.19 \pm 0.10$ & & & \\
\hline PCM & 6.99 & 6.78 & 6.70 & 6.58 & 6.11 & 6.05 & 5.60 & $6.40 \pm 0.10$ & & & \\
\hline $\begin{array}{l}\text { Period } \\
\text { mean } \\
\pm \text { SEM }\end{array}$ & $7.04 \pm 0.02^{f}$ & $6.70 \pm 0.04^{e}$ & $6.47 \pm 0.11^{d}$ & $6.33 \pm 0.11^{c}$ & $5.96 \pm 0.07^{b}$ & $5.92 \pm 0.06^{b}$ & $5.66 \pm 0.03^{\mathrm{a}}$ & $6.30 \pm 0.07$ & 0.000 & 0.000 & 0.000 \\
\hline \multicolumn{12}{|c|}{$\mathrm{NH}_{3}-\mathrm{N}(\%$ of total $\mathrm{N})$} \\
\hline MS & 2.57 & 3.85 & 3.85 & 5.13 & 6.42 & 6.42 & 7.70 & $5.13 \pm 0.44$ & & & \\
\hline PCM & 7.62 & 4.57 & 4.57 & 13.71 & 9.14 & 7.62 & 12.19 & $8.49 \pm 0.78$ & & & \\
\hline $\begin{array}{l}\text { Period } \\
\text { mean } \\
\pm \mathrm{SEM}\end{array}$ & $5.09 \pm 1.24^{\mathrm{a}}$ & $4.21 \pm 0.54^{\mathrm{a}}$ & $4.21 \pm 0.42^{\mathrm{a}}$ & $9.42 \pm 1.99^{\mathrm{cd}}$ & $7.78 \pm 0.80^{\mathrm{bc}}$ & $7.02 \pm 0.58^{b}$ & $9.94 \pm 1.13^{d}$ & $6.81 \pm 0.51$ & 0.000 & 0.000 & 0.000 \\
\hline
\end{tabular}


Table.3 Periodic live weight $(\mathrm{kg})$ of experimental goats during feeding-cum-metabolism trial

\begin{tabular}{|c|c|c|c|c|c|c|c|c|c|}
\hline \multirow[t]{2}{*}{ Attributes/Treatments* } & \multicolumn{5}{|c|}{ Days from onset of trial } & Treatment & \multicolumn{3}{|c|}{$P$ value ${ }^{\#}$} \\
\hline & $\begin{array}{l}0^{\text {th }} \\
\text { day }\end{array}$ & $\begin{array}{l}8^{\text {th }} \\
\text { day }\end{array}$ & $\begin{array}{l}15^{\text {th }} \\
\text { day }\end{array}$ & $\begin{array}{l}22^{\text {nd }} \\
\text { day }\end{array}$ & $\begin{array}{l}30^{\text {th }} \\
\text { day }\end{array}$ & $\begin{array}{c}\text { Mean } \pm \\
\text { SEM }\end{array}$ & $\mathbf{T}$ & $\mathbf{P}$ & $\begin{array}{c}\mathbf{T x} \\
\mathbf{P}\end{array}$ \\
\hline MS & 28.9 & 26.9 & 26.5 & 26.2 & 25.6 & $26.8 \pm 1.18$ & & & \\
\hline PCM & 29.0 & 27.2 & 27.7 & 26.9 & 26.3 & $27.4 \pm 1.09$ & & & \\
\hline Period mean \pm SEM & 28.9 & 27.1 & 27.1 & 26.5 & 25.9 & $27.1 \pm 0.80$ & 0.743 & 0.841 & 1.000 \\
\hline
\end{tabular}

*MS: Maize silage; PCM: Parthenium-Cannabis-Maize silage (30:8:60+ 2 Molasses)

${ }^{\#}$ T: treatment; P: Period; T x P: Treatment $x$ Period interaction

Table.4 Mean weekly feed intake (dry matter basis; g/d) of experimental goats fed maize silage or Parthenium-Cannabis-Maize silage

\begin{tabular}{|c|c|c|c|c|c|c|c|c|}
\hline \multirow{2}{*}{$\begin{array}{l}\text { Attributes/ } \\
\text { Treatments* }\end{array}$} & \multicolumn{4}{|c|}{ Weeks since onset of trial } & \multirow{2}{*}{$\begin{array}{c}\text { Treatment } \\
\text { Mean } \pm \\
\text { SEM }\end{array}$} & \multicolumn{3}{|c|}{ P value ${ }^{\#}$} \\
\hline & I & II & III & IV & & $\mathbf{T}$ & $\mathbf{P}$ & $\mathbf{T} \times \mathbf{P}$ \\
\hline \multicolumn{9}{|c|}{ Concentrate intake } \\
\hline MS & 229 & 217 & 215 & 213 & $218 \pm 2.89$ & & & \\
\hline PCM & 230 & 218 & 222 & 217 & $222 \pm 2.66$ & & & \\
\hline $\begin{array}{l}\text { Period mean } \\
\pm \text { SEM }\end{array}$ & $230 \pm 4.01$ & $218 \pm 4.21$ & $218 \pm 4.20$ & $215 \pm 3.34$ & $220 \pm 1.96$ & 0.416 & 0.050 & 0.948 \\
\hline \multicolumn{9}{|l|}{ Silage intake } \\
\hline MS & 533 & 638 & 699 & 786 & $672 \pm 7.39$ & & & \\
\hline PCM & 292 & 322 & 365 & 437 & $359 \pm 6.15$ & & & \\
\hline $\begin{array}{l}\text { Period mean } \\
\pm \text { SEM }\end{array}$ & $412 \pm 13.63^{a}$ & $480 \pm 17.86^{b}$ & $532 \pm 18.81^{\mathrm{c}}$ & $611 \pm 18.09^{d}$ & $516 \pm 9.55$ & 0.000 & 0.000 & 0.000 \\
\hline \multicolumn{9}{|l|}{ Total intake } \\
\hline MS & 762 & 856 & 914 & 999 & $891 \pm 8.02$ & & & \\
\hline PCM & 522 & 540 & 587 & 654 & $581 \pm 6.46$ & & & \\
\hline $\begin{array}{l}\text { Period mean } \\
\pm \text { SEM }\end{array}$ & $642 \pm 14.61^{\mathrm{a}}$ & $698 \pm 18.44^{b}$ & $751 \pm 19.33^{c}$ & $827 \pm 18.15^{\mathrm{d}}$ & $736 \pm 9.65$ & 0.000 & 0.000 & 0.000 \\
\hline
\end{tabular}

*MS: Maize silage; PCM: Parthenium-Cannabis-Maize silage (30:8:60+ 2 Molasses)

${ }^{a b c d}$ Means bearing different superscripts within the row differ significantly

${ }^{\#}$ T: treatment; P: Period; T x P: Treatment x Period interaction 
Table.5 Nutrient intake of experimental goats fed maize silage or parthenium-cannabis-maize silage

\begin{tabular}{|c|c|c|c|c|}
\hline \multirow[t]{2}{*}{ Attributes } & \multicolumn{2}{|c|}{ Treatments* } & \multirow[t]{2}{*}{ SEM } & \multirow[t]{2}{*}{ P value } \\
\hline & MS & PCM & & \\
\hline \multicolumn{5}{|c|}{ Dry matter intake } \\
\hline g/d & 1010 & 634 & 57.5 & 0.000 \\
\hline$\%$ L. Wt & 4.00 & 2.45 & 0.29 & 0.002 \\
\hline $\mathrm{g} / \mathrm{kg} \mathrm{W}^{0.75}$ & 89.0 & 55.0 & 5.86 & 0.000 \\
\hline \multicolumn{5}{|c|}{ Organic matter intake } \\
\hline $\mathrm{g} / \mathbf{d}$ & 884 & 566 & 48.6 & 0.000 \\
\hline$\%$ L.Wt & 3.50 & 2.19 & 0.25 & 0.002 \\
\hline $\mathrm{g} / \mathrm{kg} \mathrm{W} \mathbf{W}^{0.75}$ & 78.0 & 49.0 & 5.00 & 0.000 \\
\hline \multicolumn{5}{|c|}{ Crude protein intake } \\
\hline g/d & 123.7 & 82.2 & 6.56 & 0.000 \\
\hline$\%$ L.Wt & 0.49 & 0.32 & 0.03 & 0.001 \\
\hline $\mathrm{g} / \mathrm{kg} \mathrm{W}^{0.75}$ & 10.89 & 7.11 & 0.63 & 0.000 \\
\hline
\end{tabular}

*MS: Maize silage; PCM: Parthenium-Cannabis-Maize silage (30:8:60+ 2 Molasses)

Fig.2 Mean weekly feed intake (dry matter basis; g/d) of experimental goats fed maize silage or parthenium-cannabis-maize silage

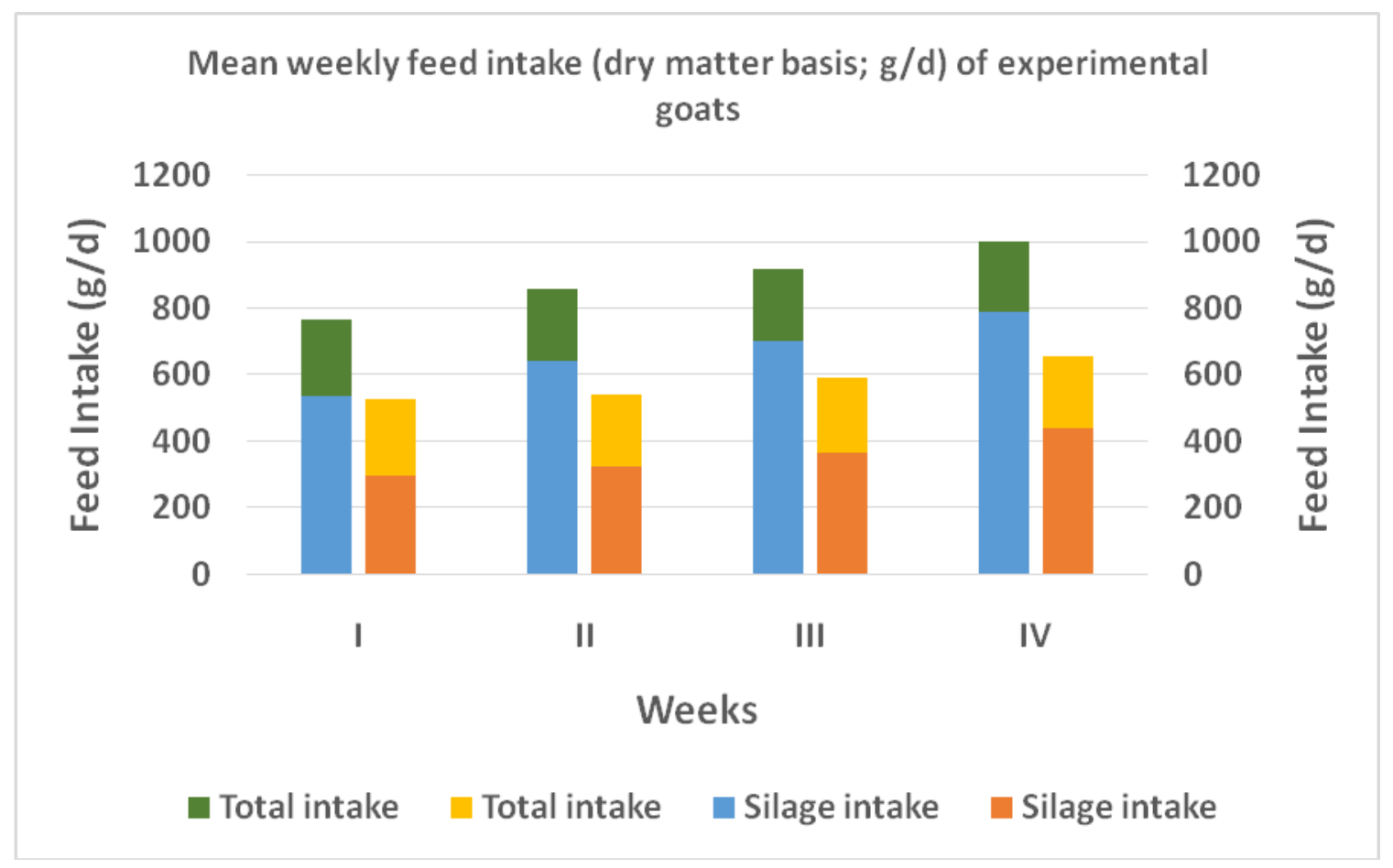


Table.6 Nutrient digestibility (\%) in experimental goats fed maize silage or partheniumcannabis-maize silage

\begin{tabular}{|l|c|c|c|c|}
\hline \multirow{2}{*}{ Attributes } & \multicolumn{2}{|c|}{ Treatments* } & \multirow{2}{*}{ SEM } & \multirow{2}{*}{ P value } \\
\cline { 2 - 5 } & MS & PCM & & \\
\hline Dry matter & 68.08 & 65.56 & 1.43 & 0.404 \\
\hline Organic matter & 70.27 & 67.98 & 1.26 & 0.390 \\
\hline Crude protein & 69.23 & 72.43 & 1.40 & 0.271 \\
\hline Ether extract & 82.03 & 85.70 & 1.54 & 0.249 \\
\hline Crude fibre & 68.58 & 55.31 & 2.83 & 0.010 \\
\hline Nitrogen free extract & 70.53 & 73.51 & 1.59 & 0.373 \\
\hline Neutral detergent fibre & 70.05 & 57.35 & 2.35 & 0.001 \\
\hline Acid detergent fibre & 55.01 & 49.71 & 2.52 & 0.315 \\
\hline
\end{tabular}

*MS: Maize silage; PCM: Parthenium-Cannabis-Maize silage (30:8:60+ 2 Molasses)

Fig.3 Nutrient digestibility (\%) in experimental goats fed maize silage or parthenium-cannabismaize silage

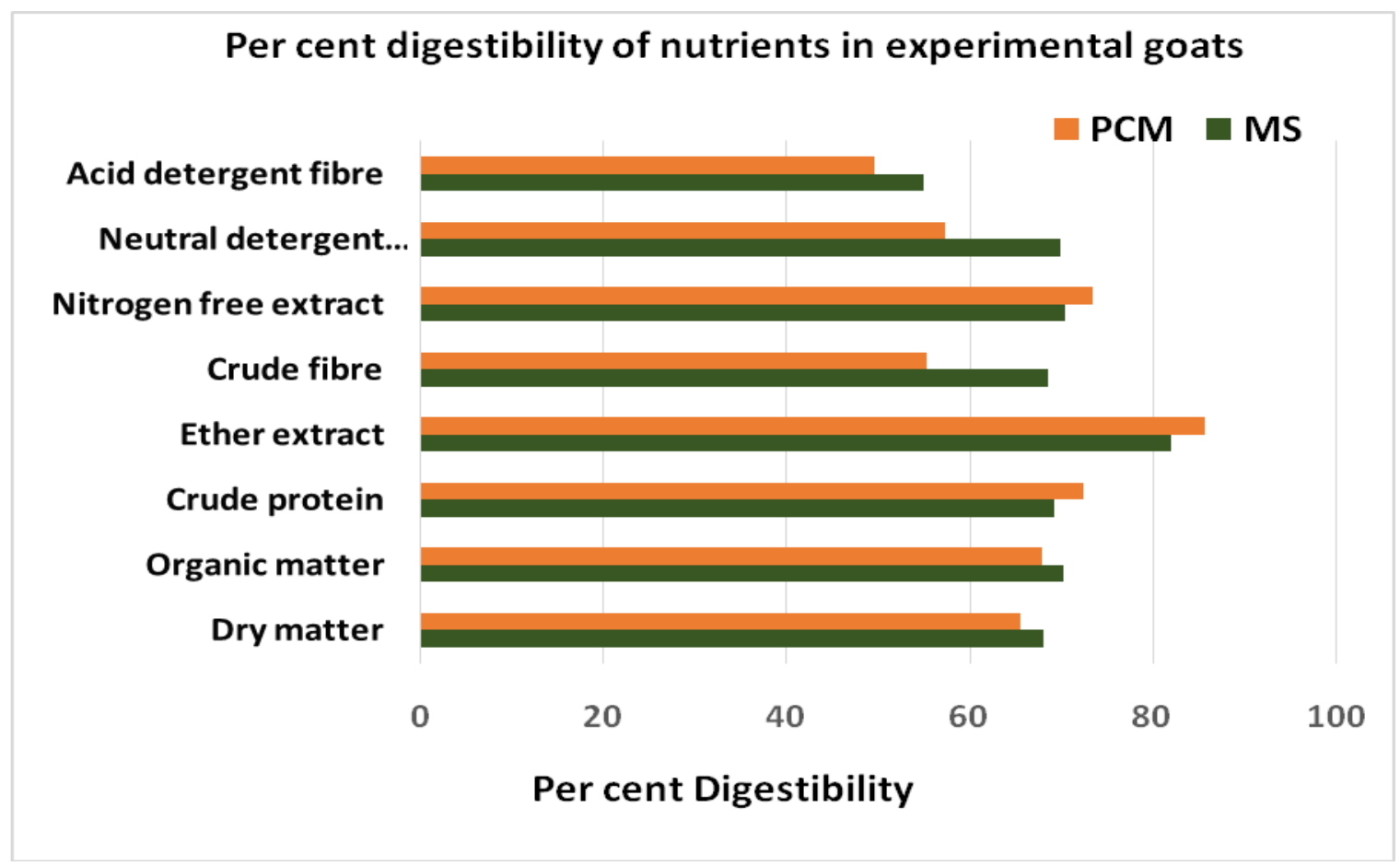


Table.7 Nitrogen balance in experimental goats fed maize silage or parthenium-cannabis-maize silage

\begin{tabular}{|l|c|c|c|c|}
\hline \multirow{2}{*}{\multicolumn{1}{|c|}{ Attributes }} & \multicolumn{2}{c|}{ Treatments* } & \multirow{2}{*}{ SEM } & \multirow{2}{*}{ P value } \\
\cline { 2 - 4 } & MS & PCM & & \\
\hline Nitrogen intake & 19.80 & 13.16 & 1.05 & 0.000 \\
\hline g/d & 0.08 & 0.05 & 0.005 & 0.001 \\
\hline \% L. Wt. & 1.74 & 1.14 & 0.10 & 0.000 \\
\hline g/kg W.75 & \multicolumn{3}{|l}{} & \\
\hline Nitrogen excretion (g/d) & 6.11 & 3.63 & 0.46 & 0.001 \\
\hline Faeces & 2.95 & 2.77 & 0.53 & 0.877 \\
\hline Urine & 9.06 & 6.40 & 0.76 & 0.079 \\
\hline Total & 10.74 & 6.76 & 0.85 & 0.011 \\
\hline Nitrogen balance (g/d) & & & & \\
\hline Nitrogen Retention & 54.47 & 51.27 & 3.67 & 0.684 \\
\hline \% of Intake & 78.14 & 71.07 & 4.85 & 0.493 \\
\hline \% of absorbed & & & & \\
\hline
\end{tabular}

The mean DMI, OMI and CPI (g/d) was significantly higher $(\mathrm{P}<0.01)$ in Maize silage fed group (1010, 884 and 123.7, respectively) as compared to PCM silage fed group (634, 566 and 82.2, respectively). Similar results were observed when the intake was expressed as percentage of live weight and $\mathrm{g} / \mathrm{kg}$ $\mathrm{W}^{0.75}$.The digestibility (\%) of nutrients from maize silage or PCM silage based regimen in experimental goats is presented in table 6 and is depicted in figure 3 . The digestibility $(\%)$ of $\mathrm{CF}$ (68.58 and 55.31, respectively) and NDF (70.05 and 57.35, respectively) was significantly higher $(\mathrm{P} \leq 0.01)$ in $\mathrm{MS}$ fed goats as compared to PCM fed goats. The digestibility (\%) of DM (68.08 and 65.56, respectively), OM (70.27 and 67.98, respectively), CP (69.23 and 72.43, respectively), EE (82.03 and 85.70, respectively), NFE (70.53 and 73.51, respectively) and ADF (55.01 and 49.71, respectively) were however, comparable ( $\mathrm{P}>0.05)$ among MS and PCM group animals. The nitrogen balance in experimental goats is presented in table 7 . Daily intake $(\mathrm{g} / \mathrm{d}, \% \mathrm{LW}$ or $\mathrm{g} / \mathrm{kgW}^{0.75}$ ) and faecal excretion of nitrogen was significantly higher $(\mathrm{P}<0.01)$ in $\mathrm{MS}$ group, leading to lower $(\mathrm{P}<0.05)$ net balance of $\mathrm{N}(\mathrm{g} / \mathrm{d})$ in PCM fed animals. Nitrogen retention expressed as per cent of nitrogen intake and as per cent of nitrogen absorbed was similar $(\mathrm{P}>0.05)$ in both the experimental groups.

\section{References}

Bhoyar, M.G., Gavkare, O.J., Reddy, C.M. and Ghumare, V.S. 2014. Possible uses of Parthenium - An agricultural waste. Journal of Industrial Pollution Control, 30: 309-312.

Butsic, V. and Brenner, J.C. 2016. Cannabis (Cannabis sativa or $C$. indica) agriculture and the environment: A systematic, spatially-explicit survey and potential impacts Environmenr Research Letters, 11: 044023

Evans, H.C. 1997. Parthenium hysterophorus: a review of its weed status and the possibilities for biological control. Biocontrol News and Information, 18(3): 89-98

Febles, E. 2018. NCSU Researchers Wrap-Up Initial Hemp in Animal Feed Trial. NC 
State Extension, NC State University, North Carolina. https://industrial hemp.ces. ncsu.edu

Duncan, B.B. 1955. Multiple range and multiple ' $F$ ' test: Biometrics, 11: 1-42.

Ghosh, S., Haldar, S., Shubhaneel, N., Ganguly, A. and Chatterjee, P.K. 2012. Kinetic study of the acid hydrolysis of Parthenium hysterophorus L. for xylose yield in the production of lignocellulosic ethanol. IOSR Journal of Pharmacy and Biological Sciences, 3(3): 35-41

Javaid and Shahfique, S. 2010. Seasonal pattern of seed dormancy in Parthenium hysterophorus L. Pakistan Journal of Botany, 42(1): 497-503.

Khaket, T.P., Aggarwal, H., Jodha, D., Dhanda, S. and Singh, J. 2015. Parthenium hysterophorus in current scenario: A toxic weed with industrial, agricultural and medicinal applications. Journal of Plant Sciences, 10: 42-53.
Kushwaha, V.B and Maurya, S. 2012. Biological utilities of Parthenium hysterophorus. Journal of Applied and Natural Science, 4(1): 137-143.

Kumar, M. and Kumar, S. 2010. Effect of Parthenium hysterophorus ash on growth and biomass of Phaseolus mungo. Academia Arena, 2(1): 98-102.

Nelson, R.A. 2000. Hemp Husbandry (Internet edition). https://www. hempbasics.com/hhusb/hh11stcr.Htm\# HH110

Saini, A., Aggarwal, N.K., Sharma, A., Kaur, M. and Yadav, A. 2014. Utility potential of Parthenium hysterophorus for its strategic management. Advances in Agriculture, Article ID 381859. http://dx.doi.org/10.1155/2014/381859

Snedecor, G.W. and Cochran, W.G. 1994. Statistical methods. $8^{\text {th }}$ Edition, East West Press Private Limited, New Delhi.

\section{How to cite this article:}

Mohd Iqbal, R.K. Sharma, Ankur Rastogi, Shamim Ali and Danish Bhutyal. 2018. Evaluation of Effect of Silage Prepared from Parthenium hysterophorous (Congress Grass) and Cannabis sps. (Hemp) with Maize on the Performance of Goats. Int.J.Curr.Microbiol.App.Sci. 7(12): 3245-3255. doi: https://doi.org/10.20546/ijcmas.2018.712.375 